China Perspectives

2009/4 | 2009

Religious Reconfigurations in the People's Republic of China

\title{
Three Trends in Recent Studies of Modern Chinese Literature and Culture
}

Wang Xiaoping

\section{(2) OpenEdition}

\section{Journals}

Édition électronique

URL : http://journals.openedition.org/chinaperspectives/4934

DOI : 10.4000/chinaperspectives.4934

ISSN : 1996-4617

Éditeur

Centre d'étude français sur la Chine contemporaine

Édition imprimée

Date de publication : 31 décembre 2009

ISSN : 2070-3449

Référence électronique

Wang Xiaoping, «Three Trends in Recent Studies of Modern Chinese Literature and Culture », China

Perspectives [En ligne], 2009/4 | 2009, mis en ligne le 01 décembre 2012, consulté le 21 septembre 2020. URL : http://journals.openedition.org/chinaperspectives/4934 ; DOI : https://doi.org/10.4000/ chinaperspectives.4934 
C

Three Trends in Recent

\title{
Studies of Modern Chinese
}

\section{Literature and Culture}

\author{
XIAOPING WANG
}

1 $s$ an academic discipline or field, the study of modern Chinese literature and culture in North America has seen profound changes since the late 1980s, culminating in a "theoretical turn" in the field. This new situation has produced an array of works that can be broadly classified under "cultural studies." Compared to the field in mainland China, which still stresses empirical research, in North America this theoretical turn is marked by a conscious application of various cutting-edge theories in scholarly studies that support their theoretical frameworks. Many of these works follow postmodernist and post-structuralist trends, especially in the early period of the turn. The arrival of the global media age and the ensuing media studies fever has been accompanied by the emergence of a new tendency that emphasises studying literary and cultural texts and phenomena from the perspective of cultural production. The scholarship in the field has generally followed the theoretical paradigm-shift seen in the Anglo-American world: from structuralism to post-structuralism, from historicism to New Historicism, and from modernist-oriented New Criticism to postmodern, postcolonial criticism. Recent years have seen the emergence of a renewed interest in historical experience, which in turn has proven conducive to the formation of a hermeneutical paradigm.

\section{Postmodern and postcolonial criticism}

Postmodern theory holds that various "grand narratives," such as modernity and revolution, in their teleological narrative of a linear, progressive modernity, all disregard the plurality of historical experience and repress alternative choices and opportunities. As a counter-move, postmodernists stress local experience, "suppressed voice," and exploration of "plural modernities." (1) This tendency in the field manifests itself mainly in critiques of the "May-Fourth paradigm" as a master narrative, and the argument for "repressed modernities" existing in the late Qing period.
David Wang Der-Wei has strongly advocated this thesis over the last decade, especially in his work Fin-de-siecle Splendor: Repressed Modernities of Late Qing Fiction, 18491911. ${ }^{(2)}$ In this highly influential and inspiring book, Wang argues that promising sprouts of incipient modernity burgeoned in the late Qing period, but were either eradicated or repressed following the May Fourth transformation. In challenging the orthodox view of May Fourth literature as the beginning of modern Chinese literature, this thesis provides many insights for studying late Qing literature.

Over the years, however, challenges have arisen to Wang's thesis, in particular regarding its concept of "modernity." Disparaging the May Fourth pursuit of (literary) modernity, Wang persistently contends that in their effort to save and change China, writers of the period passionately and blindly embraced any "newness" from the Western world, yet their "discourse of the modern" was less modern than that of the late Qing period, which was imbued with an energetic spirit of experimentation. Yet if the modern or modernity only refers to the new and the innovative, we might say the modern has appeared numerous times in human history, and the term therefore becomes vacuous.

The crucial point lies in identifying modernity. Anthony Giddens defines it as the emergence of industrialisation, imperialism, nation-states, etc., terms that for the most part refer to concrete institutions or historical phenomena, ${ }^{(3)}$ while Jameson connects it with the new, capitalist mode of production. ${ }^{(4)}$ In terms of cultural modernity, the "modernness" of the May Fourth period lies in the spread and entrenchment of modern Western ideas (science, democracy, liberty, equality, individualism, etc.), which formed the base

1. See Steven Best and Douglas Kellner, Postmodern Theory: Critical Interrogations, Basingstoke, Macmillan, 1991.

2. David Wang Der-wei, Fin-de-siecle Splendor: Repressed Modernities of Late Qing Fiction, 1849-1911, Stanford, Stanford University Press, 1997.

3. Anthony Giddens, The Consequence of Modernity, Stanford, Stanford University Press 1991.

4. Fredric Jameson, A Singular Modernity: Essay on the Ontology of the Present, London, Verso, 2002 
on which intellectuals envisioned a modern world for the Chinese. In the West, modern ideas had become institutionalised in the course of fundamental social, political, and cultural changes over hundreds of years; for China, the pursuit of modernity as new set of social and economic as well as political and cultural institutions by which to reorganise the nation and society in a belated industrial stage had substantial significance: it was not blindly dreaming up something that was "new" in a merely discursive sense.

However, confusion between the substance and the discourse of the modern is evident throughout the book's discussion of four fictional sub-genres. In the analysis of chivalric and court-case fiction, on the one hand, Wang acknowledges that the writers "continued under the spell of traditional concepts of legitimacy"; $;^{(5)}$ on the other, he proposes that "by flagrantly playing with the complicitous relationship between law and violence, between justice and terror," fiction "marks a radical re-thinking of legitimacy, whether imperial or ideological." ${ }^{(6)}$ Rather than serving as a form of literary modernity, however, this cynicism showcases the bankruptcy of imperial legitimacy, calling for a modern replacement. Likewise, depravity novels are said to "anticipate a new epitome of concepts such as self, sexuality, and gender in the May Fourth period," contributing to the intense interest in desire in the latter period. ${ }^{(7)}$ Yet the sexual promiscuity that imbues these novels neither offers nor heralds more equal gender relations. Thus, the word "anticipation" here does not connote a causal relationship, much less denote a modern form of literature. Here, the application of Foucauldian discourse of genealogy might be confounded with an examination of the origin itself.

Similarly, chivalric and court-case fiction are viewed as foreshadowing later concerns with patriotism, altruism, and the forms of brotherhood exemplified in revolutionary literature, a view that is also based on thematic similarity. Undoubtedly, certain elements of traditional ethics persisted in the later revolutionary era; yet this does not testify to their modernity, which is defined much more by qualitatively different elements that emerged during the epistemological shift. In a similar vein, the "moral ambiguity" illustrated through the cynicism, exaggeration, and vulgar disfiguration of reality in exposé novels is not in itself the manifestation of literary modernity, ${ }^{(8)}$ but only reveals an anxiety mired in the Hegelian "unhappy consciousness" that leads to, but has not arrived at, the stage of new reason.

In a nutshell, while self-consciously Westernised writing is only one of several forms of literary modernisation pursued at the time, this does not mean that the seeds of modernity

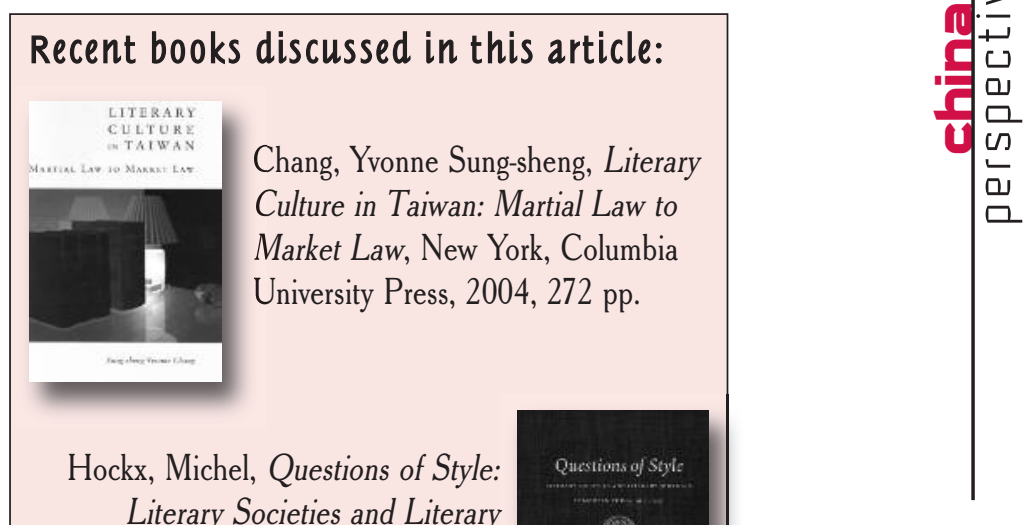

Literary Societies and Literary Journals in Modern China, 1911-1937, Leiden and Boston, Brill, 2003, 310 pp.

ILLUMINATIONS

Wang, Ban, Illuminations from the Past: Trauma, Memory, and History in Modern China, Stanford, Stanford University Press, 2004, 312 pp.

Wang, David Der-Wei, The Monster that is History: History, Violence, and Fictional Writing in Twentiethcentury China, Berkeley, University of California Press, 2004, 402 pp.
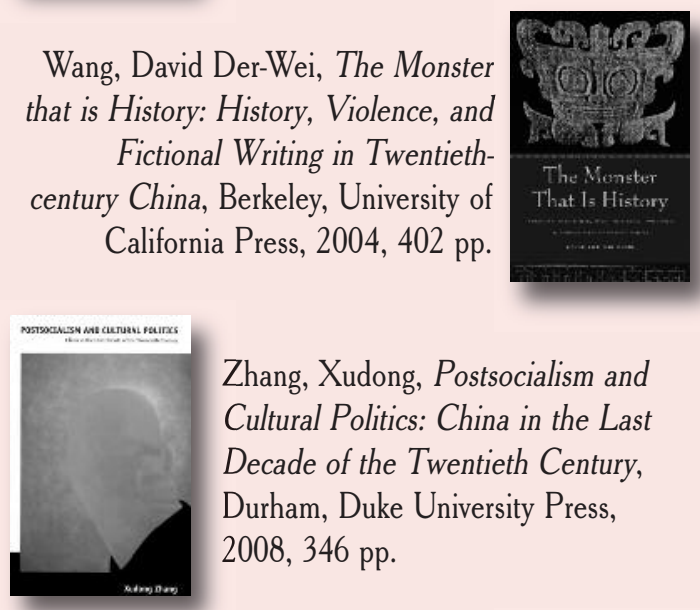

Zhang, Xudong, Postsocialism and Cultural Politics: China in the Last Decade of the Twentieth Century, Durham, Duke University Press, 2008, 346 pp.

Zhang Zhen, An Amorous History of the Silver Screen: Shanghai Cinema, 1896-1937, Chicago, University of Chicago Press, 2005, 488 pp.

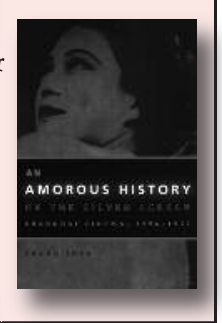

5. David Wang, Fin-de-siecle Splendor, p. 121.

6. Ibid., p. 120

7. Ibid., pp. 50, 52-61.

8. Ibid., p. 186 
would sprout from indigenous sources. The author's key concept of "involution," defined as the failure of a social or cultural pattern to transform itself into a new pattern, implies an inability to break away from tradition to achieve modernity. Put differently, most of the aforementioned novels stood at the crossroads of the traditional and the modern, but lost the competition with other emerging literary voices and experiments and were ultimately forgotten. This failure of metamorphosis from traditional to modern cannot simply be attributed to external social-political pressure, especially in light of the fact that the cultural market was still relatively autonomous and was not subject to complete political control in late Qing and Republican China.

Among the four sub-genres, only science fantasy bears the clear imprint of modernity. These works appealed to readers by dramatising new social-political ideas that combined knowledge of modern Western concepts and indigenous utopian traditions to depict scenarios that were often unimaginable in that society. Most of them were written only after Liang Qichao's 1902 promotion of a "New Novel," which aimed to propagate new Western ideas, especially political ideas calling for more enlightened and equal socio-political relations and the establishment of a "new morality." Thus, this brand of fiction does not demonstrate involution, but rather was the beginning of a revolution deriving its inspiration from imported "new" (namely "modern") ideas to experiment with literary modernity.

Through discussions of Chinese representation and conception of history in the twentieth century, David Wang's most recent work, The Monster that is History, explores the violence and brutality of twentieth-century China through a critique of enlightenment, rationality, and revolution as discourses or movements that re-envisage history in the image of a monster. ${ }^{(9)}$ In a formal analysis that sees both literature and cultural phenomena as linguistically structured texts, Wang tries to relate various sorts of violence to tradition, modernity, and Chinese identity, with a view to opening "a new critical dimension by looking into the rich repository of Chinese historiographical imagination." ${ }^{(10)}$

For this purpose, the author intentionally does not differentiate between the related subjects of history and representation, and modernity and monstrosity. This exercise is legitimised by the post-structuralist discourse to which Wang subscribes, in which history is nothing but representation; it also shows the imprint of postmodernism, in that "postmodernism is a response to a crisis of representation, and loss of faith in the truth-claims of representation." (II) Thus fiction is sometimes treated as journalistic reporting. Undoubtedly, handling texts as sociological documents or even historical facts leads to engaged and meticulous reading of various texts that debunks their ideological underpinnings, but the conflation of literary texts with historical documents is problematic, and can lead to erroneous conclusions.

Meanwhile, the question of the nature of modernity remains unclear; for instance, what constitutes the "modernity" of the violence, the "bodily rupture," or suicide that occurred in the modern era? The disenchantment with historically radical ruptures accentuates the critic's wholehearted embrace of continuity, yet this sometimes ends up creating another myth and neglecting the particular and the non-identical in history. The connection between violence and the modern, and the entanglement of revolution and modernity, call for more historical explication. Relying on thematic resemblances alone might also lead to an over-deterministic and teleological narrative. For instance, if May Fourth literature was believed to be directly responsible for the rise of Communist literature, the argument needs a historical study to explain how the former developed into the latter and under what political-cultural conditions.

The postmodern-postcolonial paradigm often engages in deconstructive analysis. The deconstruction of colonialism relied much on textual analysis, in which we continuously witness a shift from historical-social examination to discursive analysis, from interrogations pertaining to political economy towards questions regarding cultural identity.

Deconstruction, as it is commonly held, "involves the close reading of texts in order to demonstrate that, rather than being a unified whole, any given text has irreconcilably contradictory meanings." ${ }^{(12)}$ David Wang's first book, Fictional Realism in Twentieth-century China, typically applies deconstructive skills to challenge officially-sanctioned, hegemonic realism as a unified discourse, ${ }^{(13)}$ and forcefully downplays mimesis in favour of mimicry. For instance, Wang points out that Lao She's stories, rather than faithfully representing reality, "indulge in emotional spectacle, gestural hyperbole, and verbal extravagance," ${ }^{(14)}$ revealing through

9. David Wang Der-Wei, The Monster that is History: History, Violence, and Fictional Writing in Twentieth-century China, Berkeley, University of California Press, 2004.

10. Ibid., 5 .

11. Arif Dirlik, "Contemporary Challenges to Marxism: Postmodernism, Postcolonialism, Globalization," Amerasia Journal, Vol. 33, No. 3, 2007, pp. 4-5.

12. See the entry on "Deconstruction" in "Wikipedia," http://en.wikipedia.org/wiki/Deconstruction.

13. David Wang, Fictional Realism in Twentieth-century China, Mao Dun, Lao She, Shen Congwen, New York, Columbia University Press, 1992.

14. Ibid., p. 15. 
melodramatic or farcical literary technique the absurdity of Chinese reality. The book also stresses that reality is always mediated in the text: there is "a fantastic inscription of textuality and memory in a past which is always already mediated" in Shen Congwen's "self-reflexive display of nostalgia." (15) By demonstrating that there are many polyphonic, often irreconcilably contradictory elements contained in the stories of these writers, the monolithic discourse of realism is dismantled.

What should also be pointed out is that the various "realistic representations" that emerged in specific historical and political circumstances profoundly self-problematise the claim of fidelity to the real. Lu Xun acknowledged that he was not totally faithful to the real; instead, in order to adhere to the order of the revolutionaries, he deliberately added a tinge of hope by contriving a detail at the end of his story here the writer had self-consciously explored other possibilities of reality beyond any orthodox discourse of realism. Lao She's comic effects were also deliberately intended; he surely would not concern himself with any taboos of "realistic description." In this light, the monolithic discourse of realism did not have ideologically hegemonic effects on these writers; therefore, the object of deconstruction points more to the discourse of realism than to the "realistic" texts themselves. In short, the deconstructive impulse is led more by an urge to find textual evidence to support its predetermined argument than by the motivation of literary study itself. The inadequate attention given to historical experience as the condition and context of the text can therefore result in a neoformalist approach.

David Wang's three books can be seen as a coherent entity that applies postmodern epistemology to reflect on existent scholarship and remap the literary and cultural contours of modern China. They are coherent in the sense that the crisis of modernity leads to a challenge to its value-system, which furthermore leads to a re-evaluation of tradition; meanwhile, the loss of faith in modernity's truth-claims of representation leads to a re-examination of literary realism, which was the most-often used vehicle to represent reality. As noted, postmodern-oriented postcolonial criticism disclaims any essentialised identities, and tends toward "a preoccupation with fluid, unstable, and hybrid identities of borderlands against the claims of stable political and cultural entities." (16) Thus Rey Chow sets out to deconstruct "Chineseness" in her various books, revealing the historical untenability of Westernised third-world intellectuals' clinging to the illusion of return to a "pure ethnic origin." (17) In Primitive Passions, especially, the myth of origin as a traditionalist, essen- tialist discourse is legitimately debunked. But the critique often stops short of further explicating historical experience apart from discourse-deconstruction. For instance, if, as Chow acknowledges, subjectivity "is not individual but an effect of historical forces that are beyond any individuated consciousness," ${ }^{(18)}$ where this collective-based consciousness lies needs to be clarified.

Postcolonial criticism often collaborates with Western feminism to assert its critical edge. In her path-breaking (in terms of application of critical theory) work Women and Chinese Modernity, which is an interpretation of history based on literary analysis with the instrument of power-relationship analysis, Chow argues that women were "othered" for exclusion from the nation by the modernising drive that claimed to enlighten and liberate Chinese women. As a reflection, Chow proposes the possibility of a reconstruction emphasising the female body and sexuality that is repressed in World History. ${ }^{(19)}$

These arguments are inspired by a (postcolonial) feminist stance that asserts women's rights and calls attention to their repressed status. But what feminist discourse often overlooks is that the well-being of women is always subject to socioeconomic conditions. Instead of exploring real historical experience, it often projects later insights back onto the historical site. A case in point is Chow's argument that when young Chinese men in May Fourth theatres adopted Western feminism to substantiate their attacks against the Confucian establishment, it was "another way in which Western fathers subjugated and colonized non-Western women." ${ }^{200}$ Here the efforts of progressive Chinese intellectuals to liberate women from traditional oppression are not sufficiently acknowledged. Rather than assuming that there should be a postmodern feminism actively working at that time, it is necessary for us to keep the historical context in mind and focus on historical investigation; for example, to inquire why and how women were excluded from history, and under what conditions they could have avoided exclusion; or, in what historical circumstances the open staging of the female body and sexuality was possible, if it was really possible. Leaving these questions unexamined and merely holding the post-

15. Ibid., p. 21

16. Arif Dirlik, op. cit., p. 5.

17. Rey Chow, Primitive Passions: Visuality, Sexuality, Ethnography, and Contemporary Chinese Cinema, New York, Columbia University Press, 1995.

18. Rey Chow, Woman and Chinese Modernity: The Politics of Reading between West and East, Minnesota and Oxford, University of Minnesota Press, 1991, p. xii.

19. Ibid.

20. Rey Chow, Primitive Passions, p. 138 
modern feminist stance verges precariously on anachronism. The other side of this ahistorical critique of women's roles in society based on the contemporary standard of postcolonial perspective is aggrandisement. Nicole Huang's work Women, War, Domesticity, which studies Shanghai literature and popular culture of the 1940s, inflates the role of women writers in the occupied area to the extent of lionising them as the heroes of cultural construction in the era, and argues that their production was a cultural resistance and ethnography of the Chinese people. ${ }^{(21)}$ Essentially middlebrow in nature, this new boudoir literature, focusing on life in a certain class stratum, has much less to do with ethnography; it is located in a different position within genre hierarchies than the literature of cultural resistance.

In short, this trend of postmodern methodology with postcolonial critique has a tendency to embrace new historicism, which ostensibly reads texts in their contexts. Still, this study of context is not an exploration of historical genesis but an interweaving of various personal relationships, debates, memoirs, and diaries, with a tendency to project the scholar's historically-conditioned vantage-point back to the historical objects. Inspiration from the postmodern-postcolonial critical paradigm has brought many insights to modern Chinese studies; however, the various flawed arguments that have resulted also underscore the necessity to recall and reflect upon the validity and applicability of theories when applied to the study of modern Chinese literature and history.

\section{Studying works within the "field of cultural production"}

The key to genuine historicising is to explore the historical conditions and situation that explain the origin and development of a historical phenomenon. A case in point is the study of literary institutions, which are constantly changing in the frame of a cultural field. This kind of contextualised study can avoid the pitfalls of postmodern, imaginative historiography.

More than three decades ago, Leo Lee took note of the structural context of literary activities. One feature of his classic The Romantic Generation of Modern Chinese Writers that distinguishes it from previous works is its interest in literary industries. ${ }^{(22)}$ In his delineation of the cultural arena and the rise of professional writers within it, Lee's work implied the idea that a shared understanding of the role of the writer and the function of literature constitutes a cultural institution. The attention to cultural industries was continued in Perry Link's seminal work studying "Mandarin Duck and Butter- fly" writers. ${ }^{(23)}$ Edward Gunn's Unwelcome Muse, which studies Chinese literature in Shanghai and Beijing during the War of Resistance, also investigated this cultural field, ${ }^{(24)}$ but remained a form of traditional historical account by generally defining the field in terms of geographical area. Political conditions are only treated as background, and Gunn disavows any interests in the sociology of literature. The 1990s has seen the emergence of a clearer intent to delve into specific historical formations and practices based on studies of relational nexus and structural context.

In High Culture Fever, Jing Wang argues that her study of cultural experiments in contemporary China intends "to examine it in the changing context that yields different, and perhaps conflicting, vantage points"; ${ }^{(25)}$ this, however, is less a study of literature per se than of cultural politics. Lydia Liu in Translingual Practice also aims to "enter the changing field of meaning in relation to other discursive constructs" and believes that "it is only with reference to the performability of such relations that a particular construction is meaningful in its context." ${ }^{26)}$ Nevertheless, the various subjects in her project, "literature, national culture, and translated modernity," are different in nature.

In recent years, the tendency to integrate studies of cultural industry, or broadly speaking, industrialised culture, with analysis of literary works and cultural phenomena has become more salient, demonstrating increasing attention to the perspective of cultural production as a "field." Leo Lee's new book on Shanghai's modern urban culture is one of the first studies of this kind, aiming to explore "what may be called the cultural imaginary, which was a contour of collective sensibilities and significations resulting from cultural production." ${ }^{27)}$ For this purpose, Lee not only continues with his earlier interest in the industrial aspects of cultural production, but goes a step further in heeding "both the social and the institutional context" of production, such as the cultural

21. Nicole Huang, Women, War, Domesticity: Shanghai Literature and Popular Culture of the 1940s, Leiden and Boston, Brill, 2005

22. Leo Lee Ou-fan, The Romantic Generation of Modern Chinese Writers, Cambridge, Mass Harvard University Press, 1973.

23. Perry Link, Mandarin Ducks and Butterflies: Popular Fiction in Early Twentieth-Century Chinese Cities, Berkeley, University of California Press, 1981.

24. Edward Gunn, The Unwelcome Muse: Chinese Literature in Shanghai and Beijing, $1937-$ 1945, New York, Columbia University Press, 1980.

25. Jing Wang, High Culture Fever: Politics, Aesthetics, and Ideology in Deng's China, Berkeley, University of California Press, 1986, p. 6.

26. Lydia Liu, Translingual Practice: Literature, National Culture, and Translated ModernityChina, 1900-1937, Stanford, Stanford University Press, 1995, p. 197.

27. Leo Lee, Shanghai Modern: the Flowering of a New Urban Culture in China, 1930-1945, Cambridge, Harvard University Press, 1999, p. 63. 
and industrial institutions of the publishing and film industries. This approach sees urban culture as the result of a process of production as well as consumption, which involves the development of new public structures and spaces that serve as material background for new forms of cultural activity.

Nicole Huang's Women, War, Domesticity follows the same direction. It studies Shanghai literature and popular culture during the period of Japanese occupation in the 1940s, and includes an examination of the emergence of a women's print culture, especially the features of women's popular magazines. Its contextual discussions underline the analytical importance of the "field of cultural production."

However, lest literary studies become sociology, it is important to connect texts and contexts organically rather than mechanically. Currently, the two theoretical foci in the field, namely modernity and literature (or literary modernity) as an institution, play mediating roles in this connection: by focusing on modern literature as a new socio-cultural institution, they offer genuine means to achieve this synthesis.

Shu-mei Shih's methodology in The Lure of the Modern is a contextual study combined with an intrinsic analysis. She states that her intention is to chart "the interrelatedness between these extrinsic conditions and the intrinsic aspects of writing style, particularly in terms of the stylistic and aesthetic propensities." ${ }^{(28)}$ For this, she has tried to define the positions of the writers in the context of the field of cultural production in order to contextualise, for instance, the rise of jingpai writing by reinvestigating the immediate post-May Fourth cultural formation. Nevertheless, the way she ties these two aspects together, through the different attitudes of writers towards cosmopolitan culture and colonial culture, leaves out many writers who belong to the two schools she studies but who do not show the same degree of "modernist techniques." Also, this framework, on its own, cannot account for textual features.

With the coming of a media-centred age, media studies have become a favourite subject, and one in which the tendency to study cultural production in its own right is particularly evident. For instance, film studies of recent years have reached a consensus that the aesthetic features of individual films result from the mixing of directors' own idiosyncratic input with the forces of contemporary industrial modes of production, and therefore they cannot be considered solely on the basis of auteur theory. Hence Zhang Zhen's Amorous History of the Silver Screen, which studies early Chinese cinema, claims to combine "aesthetic analysis and semiotic exegesis in relation to both larger textual or intertextual sys- tems." (29) This should be regarded as a breakthrough in Chinese film studies, which previously either focused on state policies or merely discussed directors' individual styles. But while Zhang acknowledges that "the sociological and historical landscape I delineate along the way should not be construed as the separate means or the end of the cinematic experience as the two are inexorably interwoven," her analytic procedure follows Hans Ulrich Gumbrecht's proposal, tying in "the interests in textual "meaning-constitution" with "the concern for the body and other physical and material properties of signification." ${ }^{30)}$ From the perspective of this methodology, multifaceted film culture contributed to "the production of a sociocorporeal sensorium and a broadly defined vernacular movement." ${ }^{(31)}$ The method is still a corporeal-materialist approach that is situated mid-way towards a historical hermeneutics, with the result that Zhang's concept of a "vernacular modernism" does not fully account for the aesthetic characteristics of early Chinese films.

A few works have more or less successfully accomplished the two-end interpretation. The issue of literature as an institution in the field of cultural production in terms of the sociology of culture is the principal concern of Michel Hockx's Questions of Style, which studies modern literary societies and literary journals. ${ }^{(32)}$ The work most saliently focuses on the institutionalised aspects of cultural production. Hockx is conscious of applying Pierre Bourdieu's theory of "field of cultural production" to analyse literary institutions. Instead of treating literature in an unmediated relationship with society, Hockx sees the field as a privileged context for interpreting literature. The study's use of the Bourdieusian terminology, such as habitus and hierarchies, and its attention to distinct trajectories of writers and their activities, opens a broader horizon on literary activity and production.

The major invention here is a new concept of style, which refers to a conglomeration of features involving language (form and content), lifestyle, style of organisation of literary activity and production, and style of publication. ${ }^{(33)}$ This concept is helpful in switching attention to the collective features of literary production, but its framework may also be over-

28. Shu-mei Shih, The Lure of the Modern: Writing Modernism in Semicolonial China, 19171937, Berkeley, University of California Press, 2001, p. 257.

29. Zhang Zhen, An Amorous History of the Silver Screen: Shanghai Cinema, 1896-1937, Chicago, University of Chicago Press, 2005, p. xxviii.

30. Ibid., pp. xxviii-xxviv.

31. Ibid., p. xxx

32. Michel Hockx, Questions of Style: Literary Societies and Literary Journals in Modern China, 1911-1937, Leiden and Boston, Brill, 2003.

33. Ibid., p. 13. 
loaded with too many heterogeneous elements, making it difficult to analyse either individual works or general phenomena. ${ }^{(34)}$ This departure from Bourdieu's theory, which was intended as a development through adaptation, might not have entirely attained its goal.

A minor problem, acknowledged by the author, is the work's emphasis "on literary practice, on the activities of the people involved in literary production, rather than on analysis of the text they produced." ${ }^{(3)}$ Put other way, his analysis complements textual analysis rather than replacing it. Yet, by leaving out the consideration of individual texts, its value in judging literarity, or literariness, as Bourdieu in his theory has promised us, is greatly decreased. Generally speaking, however, Hockx's shift in focus from author studies to the economic aspects of literary production, as well as the reader's role as consumer, pilots a new, heuristic, and sociological direction.

Within the distinct trend towards studies of "field of cultural production," Sung-Sheng Chang's Literary Culture in Taiwan tries to address these shortcomings by comprehensively and proficiently applying Bourdieu's theory. ${ }^{(36)}$ First, changes in the political parameters of Taiwan occupy an important place in her discussions of the shifts in Taiwan's cultural field, which wrought profound changes in its literature. Second, Chang makes a careful categorisation of different positions of writers and schools that correlate with different types of political/cultural capital and interplay with each other. Third, in studying the paradigm-shift of cultural production since the 1980s, she points out that the entire cultural field was gradually freed from political subjugation and gained relative autonomy, with a new cultural principle of legitimacy superseding political principle. Meanwhile, writers' production was increasingly subjected to the mandate of market forces as a "heterogeneous principle." Fourth, she investigates both elite literature and popular cultural products and explores their mutual influences and penetration. In elaborating these ideas, the book focuses on such key concepts as hegemonic discourse, hierarchy in genre and style, and autonomous/heteronomous principles of hierarchisation. The last but not least distinct feature of the work is that Chang incorporates ideological analysis, in particular class analysis, in her discussion of the different positions. In short, Chang adds depth to the scope opened up by Hockx.

The application of the theory of "field of cultural production" to the study of literary arts can explain the production of texts within certain political circumstances and in specific cultural fields, and to a certain extent literary characteristics of texts, and thus has received increasingly favourable con- sideration in recent years. Nevertheless, its exclusive focus on the relatively fixed structure of the field prevents it from serving as a dynamic model that explains historical experience, and therefore from fully explicating the aesthetic details of cultural works, or how individual works can transform the field. In order to grasp structural transformations in the cultural fields in their historical motions, therefore, this methodology needs to work in tandem with another perspective that has gradually emerged as a third trend in our field.

\section{The practice of historical hermeneutics}

Marston Anderson's The Limits of Realism: Chinese Fiction in the Revolutionary Period can be seen as the beginning of this new theoretical direction. ${ }^{(37)}$ Through "a kind of archaeological investigation," Anderson explores the connotations of realism as situated in theoretical, and more importantly, historical, contexts, thus differentiating it from various other kinds of realism (classical, critical, revolutionary, and socialist) in other periods. It goes a step further towards a historical explanation.

A flaw of the book is that it falls short of fully explaining the metamorphoses of realistic writings. Anderson follows the conventional argument that modes of realistic writing changed because the "old realism came finally to seem powerless to repair the cultural schism that opened in China after the fall of the traditional world order." ${ }^{(38)}$ This explanation is only a partial and subjective observation. Perhaps it is less the intrinsic shortcomings of any brand of realism per se than historical forces that spurred these variations in style. Here, the historical experience is not merely the context, but more fundamentally becomes the subtext. For instance, the reason for the disintegration of old realism with the emergence of the crowd and then the masses is not merely the force-play within the texts, but needs to be investigated by studying the historical experience crystallised and articulated in the texts. In these texts, the individual is first inundated by the ignorant "crowd," and then the crowd is replaced by the revolutionary "masses." In other words, explaining aes-

34. It is made more confused by its integration into a larger concept of "normative form," defined as "a constellation of style, language, context and personality." Ibid., p. 221.

35. Ibid., p. 6 .

36. Yvonne Sung-sheng Chang, Literary Culture in Taiwan: Martial Law to Market Law, New York, Columbia University Press, 2004.

37. Marston Anderson, The Limits of Realism: Chinese Fiction in the Revolutionary Period, Berkeley, University of California Press, 1990

38. Ibid., p. 202 
thetic details of texts requires combining analyses of literary contents and historical subtexts in an organic way.

Ban Wang's The Sublime Figure of History proposes that a "sublime figure" defines and circumscribes the making of Maoist revolutionary discourse, ${ }^{(39)}$ revealing hidden links among official ideology, mass psychology, and individual aesthetic experiences. Wang's psychoanalytic approach, which delves into psychosomatic aspects to account for the interplay between the political and the aesthetic, is both refreshing and problematic, mainly because the Freudian and Lacanian models of psychological interpretation cannot be assumed to be historically scientific and universal. Wendy Larson thus challenges Wang's holistic assumption that erotic desire was transformed into revolutionary passion under Maoism, which is the key premise of the author's whole elaboration. ${ }^{(40)}$ Consequently, although the book ostensibly refutes the prevalent cold-war assumption that a mechanical brain-washing took place in Mao's China, it in fact never departs from this mode of thinking (e.g., he also holds that social ritual mimics "the psychic operation of hypnosis"), ${ }^{(41)}$ but merely contributes to a more psychoanalytical affirmation of the thesis. Why and how the sublime effects were widely produced and accepted, and the collateral issue, why and how they were debunked and became disenchanted, are the content of real historical experience, but are not treated. Wang's linking of the individual body and the body politic mainly by philosophical and literary discussion, but not by historicising the doubtable causal link, causes a short circuit in his line of reasoning.

Indeed, organically integrating internal interpretation and external explication requires attending to the dialectics of form and content. In this regard, the same author's new book, IIluminations from the Past, progresses further in this direction. ${ }^{(42)}$

The book can be read as a succinct cultural history of modern China in the past century. As historical catastrophes characterise modern China, its literary writing is underscored by traumatic experience. The author's approach is to see through the textual surface into the historical depth by analysing how literary expressions articulate the historical unconscious. Thus, he either examines the modes of representing catastrophic histories in Xiao Hong's novels, or explores the decline of history and the loss of communal value in the age of commercialisation in Wang Anyi's (auto-)biographical novel, both of which chronicle the historical development of Chinese modernity. This approach is not only helpful for understanding how the texts represent history, but is also instrumental in exploring how historicity can be textu- alised and visualised. This analysis relies not on discussions based on a historiographical imagination, but on the articulation of the historicity of representation and the representation of history through the mutual mediation of texts and historical experience. In this way, it represents a departure from Wang's earlier methodology and a step closer to historical hermeneutics.

To pursue historical hermeneutics is to inquire why and how different class consciousness (refracted by the habitus and in the writing practices of individual writers) and historical conditions circumscribed writers to recognise the political situation and propelled them to carry out their aesthetic ideal, leaving traceable signatures and imprints in their works waiting to be deciphered. To put it in another way, the semiotic system of literary texts is broken down to show history and politics, just as history and politics are examined to make them speak to the semiotic system.

In this respect, Xudong Zhang's Chinese Modernism in the Era of Reforms provides a reference point for this double analytic movement. ${ }^{(43)}$ The work is a discerning analysis of theoretical debates, modernist poetry, fiction, and Chinese new cinema in the 1980s. It applies a dialectical framework to the relationship between aesthetic modernism and political and economic modernity, which contextualises the internal structure of aesthetic texts.

The most promising prospectus this method brings to literary studies is evident first and last at the textual level: by inexorably historicising, it can explain the most idiosyncratic aesthetic details. In an analysis of the image of the hero "Grandpa" in the film Red Sorghum, for instance, Zhang sees him as an expression of historical "truth-content": While on the one hand he embodies "a new, far more dynamic historical agency, whose recognised value is unmistakably spelled out as commodity" with even a fascist impulse in the reform era, he on the other hand "transgresses not only peasant ethics but the capitalist rationale of the social organisation of labor and profit making as well," with its "source of productivity and enjoyment" coming from "a transformed and motivated communal life, from a deep-

39. Ban Wang, The Sublime Figure of History: Aesthetics and Politics in Twentieth-century China, Stanford, Stanford University Press, 1997.

40. Wendy Larson, "Review: The Sublime Figure of History," In Comparative Literature, Vol. 50, No. 2, 1998, p. 191

41. Ban Wang, The Sublime Figure of History, p. 217.

42. Ban Wang, Illuminations from the Past: Trauma, Memory, and History in Modern China, Stanford, Stanford University Press, 2004.

43. Xudong Zhang, Chinese Modernism in the Era of Reforms: Cultural Fever, Avant-garde Fiction, and the New Chinese Cinema, Durham, Duke University Press, 1999. 
seated value system reinforced by a new enthusiasm for action and adventure, from something benign that, once reactivated, would create a spectacular world of its own," (44) which articulates the political unconscious of the New Era. In short, it is an expression of an ideology as well as a utopia. Here historical hermeneutics translate, or decode, a work (either realistic or modernist) as an account (either through conscious expression or unconscious crystallisation and articulation) of historical experience. Through a virtuoso hermeneutical drill, the socio-political, the historical, and the aesthetically textual finally illuminate each other.

This approach carries over to Zhang Xudong's most recent book, Postsocialism and Cultural Politics, which can be seen as the continuation of the former book in its discussion of China's culture since the 1990s. ${ }^{(4)}$ Zhang employs here a new term, "postsocialism," to define contemporary China's social-economic as well as cultural configuration. Chinese postsocialism is articulated in the cultural arena mainly through the discourses of postmodernism and nationalism, which not only play discursive functions, but are also mediated by the co-existence of multiple modes of production and socio-cultural norms, thus mixing different "temporal-historical structures." (46) Aside from discussing intellectual discourses vis-a-vis the national and global over-determinations of the making of the post-Tiananmen intellectual field, Zhang analyses various narrative possibilities of this postsocialism. Examples include the relationship between mourning and allegory in Wang Anyi's literary works, between the "Demonic realism" and the "socialist market economy" in Mo Yan's fiction, and between the construction of a collective memory and the assertion of a unique cultural/political legitimacy in the cinematic discourse of two films. Throughout the book the analysis convincingly demonstrates "the way in which readings of novels, films, social and political texts, and the polemics around them" are "positioned to illuminate each other." ${ }^{(47)}$

\section{Conclusion}

These three methodological trends bear out the fact that in recent years the concepts of "modernity," "modern," and "modernism" have become self-renewing focuses for scholarly contestation in this field. ${ }^{(48)}$ In various ways, scholars try to explicate the intricate connectedness, or organic relationship, between modern China's political-social modernity and literary modernity.

The "Chinese modern" was a process of nation-state building to which more than a century of revolution and moderni- sation efforts contributed. The contention for the Chinese modern involved not only struggles between different political forces, but also a vying for legitimacy among different versions of modern Chinese literature as conceptual and social institutions. Chinese literary modernity thus contains not only different literary narratives such as enlightenment narrative and national-salvation narrative, but also involves the establishment and institutionalisation of divergent modern modes of cultural production, and the development of differing forms of modern popular culture. In an effort to study these diversified conditions and contending voices coexisting in the tumultuous age of modern China, with its rapid and radical restructuring of cultural fields and shifting paradigms of cultural production, the application of Pierre Bourdieu's theory of cultural production has in recent years been gradually combined with the approach of historical hermeneutics to evolve towards a more dialectical and comprehensive interpretive methodology in studying modern Chinese literature and culture.
44. Ibid., p. 324.
45. Xudong Zhang, Postsocialism and Cultural Politics: China in the Last Decade of the Twentieth Century, Durham, Duke University Press, 2008.
46. Ibid., p. 188.
47. The remarks are made by Fredric Jameson; see the back cover of the book.
48. David Wang Der-wei, "A Report on Modern Chinese Literary Studies in the English Speaking World," Harvard Asia Quarterly 9, 1/2 (Winter/Spring), 2005. 